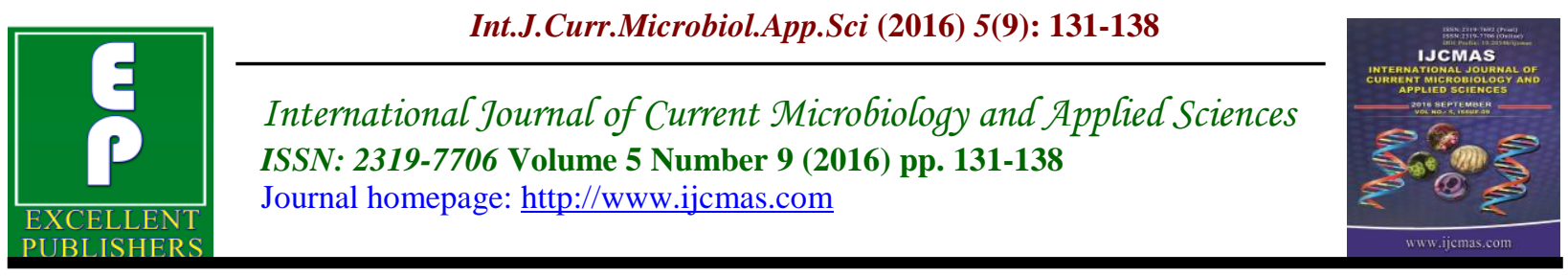

Original Research Article

http://dx.doi.org/10.20546/ijcmas.2016.509.015

\title{
Impact of Microbial Inoculants on the Performance of Bell Pepper (Capsicum annuum L.) Varieties under Foot Hills of Eastern Himalayan Region
}

\author{
Ranjit Chatterjee*, Sagar Koner and Suchand Datta \\ Department of Vegetable and Spice Crops, Uttar Banga Krishi Viswavidyalaya, \\ Pundibari, Cooch Behar, West Bengal-736165, India \\ *Corresponding author
}

Keywords

Azotobacter,

bell pepper,

microbial

inoculants,

phosphorus

solubilizing

bacteria,

qualities, yield.

\section{Article Info}

Accepted:

08 August 2016

Available Online:

10 September 2016

\section{A B S T R A C T}

An experiment was undertaken to study the influence of Azotobactor and Phosphate Solubilizing Bacteria containing microbial inoculants on the growth yield and quality of bell pepper varieties at UBKV, Pundibari, Cooch Behar, West Bengal. The experiment was laid out in split plot design with three replications. Treatments consisted of four bell pepper varieties viz, Mekong $\left(\mathrm{V}_{1}\right)$, California Wonder $\left(\mathrm{V}_{2}\right)$, J K Peeyali $\left(\mathrm{V}_{3}\right)$ and Asha $\left(\mathrm{V}_{4}\right)$, allotted in main plot whereas microbial inoculants treatments (with and without inoculation) were taken as sub plot. The pooled results indicated that seedling root dipping in microbial inoculants had enhanced the performance of bell pepper varieties. Days to $50 \%$ flowering and fruit maturity were advanced whereas fruit weight and yield were found superior in presence of microbial inoculants. The varietal performance showed that Mekong emerged as best in respect to number of fruits/plant and fruit yield whereas, Asha found best for individual fruit weight $(84.82 \mathrm{~g})$. The variety California wonder resulted excellent quality fruit in terms of highest beta carotene content and vitamin $\mathrm{C}$ content. The variety Asha in presence of microbial inoculants produced earliest flowering (83.71 days), fruit maturity (101.19 days) and highest fruit weight (92.16 $\mathrm{g}$ ), where as the variety Mekong treated with microbial inoculants gave the maximum number of fruits/plant(10.02) and highest fruit yield (701.16 g/plant and $17.98 \mathrm{t} / \mathrm{ha})$.

\section{Introduction}

Bell pepper or sweet pepper is one of the most popular luxury vegetable belongs to family Solanaceae. The crop is grown extensively in sub-temperate to sub tropical parts of India. The fruit is rich in nutritional substances especially in vitamin $\mathrm{A}$ and vitamin $\mathrm{C}$ which act as potential antioxidants. According to Hazra et al., (2011), the flavonoids present in bell pepper particularly quercetin, kaempferol, myricetin and luteolin are responsible for induction of enzymes that detoxify carcinogens. The climatic condition of foot hill of eastern Himalayan region is very conducive for bell pepper cultivation. The growing consumer demand, lucrative return and profitability attracting the small and marginal farmers towards bell pepper cultivation in winter 
season. However the cultivated varieties suffer from low yield due to sensitivity to soil and environmental variation. Several research finding suggested that adoption of microbial inoculants can minimize the soil and environmental stress and can enhance the productivity of the crop (Kute, 1997; Mohammadi and Yousef, 2012). When microbial inoculants are applied as seed or soil inoculants, they multiply and participate in nutrient cycling and benefit the crop productivity (Singh et al., 2011). The stimulatory effect exerted by microbial inoculants has been attributed to several mechanisms including secretion of phytohormones, vitamins, biological nitrogen fixation, resistance to pathogen and enhancement of mineral uptake by plants enhances the growth and yield attributes besides helps to overcome soil and environmental stresses (Fattah, 2013 ; Sahoo et al., 2013). Apart from these, phosphate solubilizing bacteria (PSB) increases the solubility of insoluble phosphorus of the soil through the production of aliphatic and aromatic acids, phytase and phospholipase (Kumar and Ahlawat, 2006). However, information on the performance of the bell pepper varieties on seedling root dipping with Azotobactor and PSB containing microbial inoculants is still scanty in the region. Keeping this in view, the present experiment was designed to study the effect of seedling dipping with microbial inoculants on growth, yield and quality parameters of different bell pepper varieties.

\section{Materials and Methods}

The experiment was conducted during winter season of 2011-12 and 2012-2013 at the experimental farm of Uttar Banga Krishi Viswavidyalaya, Pundibari, Cooch Behar $\left(89^{\circ} 23^{\prime} 53^{\prime \prime} \mathrm{E}\right.$ longitude and $26^{\circ} 19^{\prime} 86^{\prime \prime} \mathrm{N}$ latitude and at $43 \mathrm{~m}$ above mean sea level). The area is characterized by high relative humidity and a prolonged winter with high residual soil moisture. The temperature range of this area varies from minimum of $7-8^{\circ} \mathrm{C}$ to maximum of $24-33.2^{\circ} \mathrm{C}$. The experimental soil was sandy clay loam having $\mathrm{P}^{\mathrm{H}} 5.96,0.83 \%$ organic carbon, $172.79 \mathrm{~kg} / \mathrm{ha}$ available nitrogen, $22.15 \mathrm{~kg} / \mathrm{ha}$ available phosphorus and $123.25 \mathrm{~kg} / \mathrm{ha}$ available potash. The experiment was laid out in split plot design with three replications. Main plot consists of 4 bell pepper varieties and sub plot included microbial inoculants treatment (with or without microbial inoculants). Four popular bell pepper varieties namely, Mekong, JK Peeyali, Asha and California Wonder were taken in this experiment. Bell pepper seedlings were transplanted in $3 \mathrm{~m} \mathrm{x} 3 \mathrm{~m}$ plots with both ways spacing of $60 \mathrm{~cm}$ on $30^{\text {th }}$ November for both the years. The microbial inoculants Azophos containing Azotobacter chroococcum and Phosphate Solubilizing Bacteria (Acinetobacter sp) with standard microbial population $\left(5 \times 10^{8}\right)$ was used in the experiment. The microbial inoculants were applied just before transplanting as seedling root dipping at 250 $\mathrm{g} /$ litre of water using rice gruel as adhesive. Farmyard manure (20 t/ha) was applied to the respective plots at the time of transplanting. The recommended doses of inorganic fertilizers $\left(120 \mathrm{~N}: 60 \quad \mathrm{P}_{2} \mathrm{O}_{5}: 60\right.$ $\mathrm{K}_{2} \mathrm{O} \mathrm{kg} / \mathrm{ha}$ ) were applied in the form of urea $(\mathrm{N})$, single super phosphate $(\mathrm{P})$ and muriate of potash (K). Full dose of phosphorus and potash along with half nitrogen were applied as basal and rest amount of nitrogen was top dressed after 30 days transplanting. The crop was raised adopting standard package practices. The observations were recorded on ten randomly selected plants from each plot on different growth, yield and quality attributes. The chlorophyll content of leaf was measured by using portable leaf chlorophyll meter (Minolta, Japan) and express in terms of SPAD 502 value. Total 
soluble solids (TSS) were measured using a hand refractometer at $0-32^{\circ}$ Brisk scale (Erma, Japan). The vitamin $\mathrm{C}$ content was determined titrimetrically, using 2, 6 dichlorophenol indophenol dye as per method suggested by Ranganna (2001). Two years data from different treatments were subjected to statistical analysis. The data for individual year was computed and pooled mean was worked out. All analyses were performed using INDOSTAT version 8.0 statistical package.

\section{Results and Discussion}

\section{Effect of microbial inoculants}

The results of the present experiment showed that seedling root dipping with Azotobactor and PSB containing microbial inoculants significantly influenced the growth and yield parameters and resulted in higher plant height $(42.97 \mathrm{~cm})$, more number of leaves/plant (176.77), wider leaf area $\left(5.85 \mathrm{~cm}^{2}\right)$ and higher Leaf chlorophyll content (59.88 SPAD value) along with in advancement of days to $50 \%$ flowering (95.94 days) and fruit maturity (120.71 days) (Table 1 and 2). Plants raised with bioinoculant treatments recorded $17 \%$ higher plant height, $8 \%$ more number of leaves/plant and 9\% larger leaf area. As a culmination of favourable growth attributes, the number of fruits/plant, fruit weight and yield/plant were markedly increased in presence of seedling bioinoculation and resulting in $9 \%, 8 \%$ and $2 \%$ improvement respectively over uninoculated plants.

The enhance efficacy of bio-inoculated treatments suggests secretion of certain growth promoting substances by bacterial inoculants and increased availability, solubility, mobility and utilization of plant nutrients resulted in increased plant growth and yield. Again, microbial inoculant carries high levels of soil enzymes and plant growth hormones which enhances microbial populations and held more nutrients over longer periods (Sindhu et al., 1997). Addition of microbial inoculants improved soil environment and favoured the growth of soil micro flora and improved the efficacy of the applied manures and fertilizers (Kaushal et al., 2011).

\section{Effect of varieties}

Bell pepper varieties showed significant differences for growth and yield attributes for both the year as well as pooled analysis (Table 1 and 2). Among the different varieties Asha recorded the maximum plant height $(45.93 \mathrm{~cm})$, largest leaf area $(6.51$ $\mathrm{cm}^{2}$ ) and highest chlorophyll content of leaves (60.44 SPAD value).

Days to flower initiation and fruit maturity showed significant variation and the variety Asha recorded the minimum days for $50 \%$ flowering (87.97 days) and fruit maturity (106.28 days) whereas, the variety California Wonder recorded maximum days for $50 \%$ flowering (105.92 days) as well as fruit maturity (135.75 days). Different varieties have unique genetic characteristic which may be the cause for different duration of flower initiation and fruit maturity to the different variety (Kumar et al., 2002). Regarding the yield attributes different varieties also showed significant variation for number of fruits/plant, fruit weight and total yield. Among the varieties, Asha recorded highest fruit weight (84.82 g) whereas Mekong recorded maximum number of fruits (9.46/plant) and fruit yield $(680.38 \mathrm{~g} / \mathrm{plant}$ and $16.39 \mathrm{t} / \mathrm{ha})$. The variety California Wonder recorded the minimum number of fruits (6.93/plant), smallest fruit weight (43.73 g) as well as lowest fruit yield (277.69 g/plant and $7.53 \mathrm{t} / \mathrm{ha})$. 
Table.1 Effect of microbial inoculants and varieties on growth attributes of bell pepper

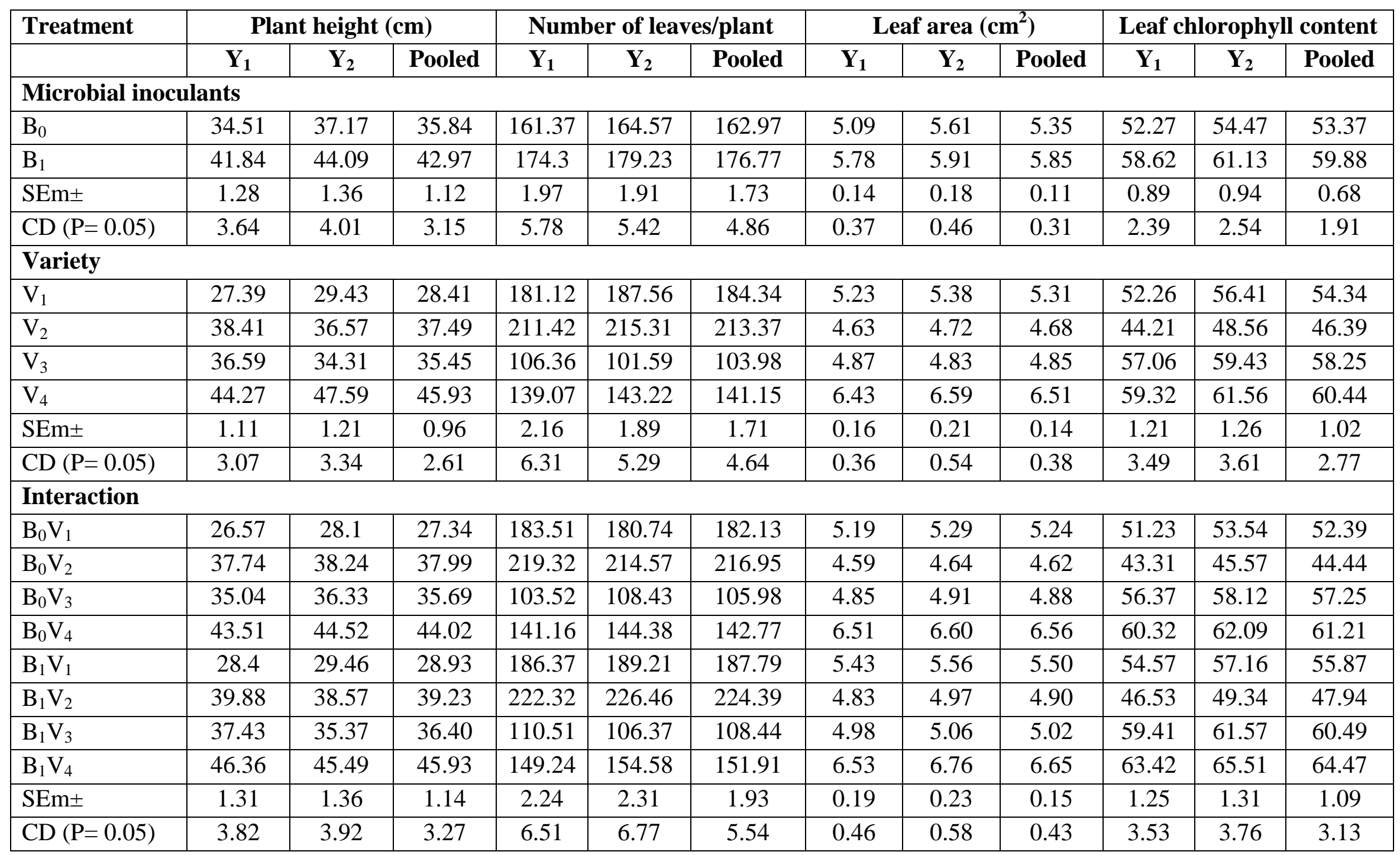

$\mathrm{Y}_{1}: 2011-12 ; \mathrm{Y}_{2}: 2012-13$; Treatments: $\mathrm{B}_{0}:$ No Microbial inoculants, $\mathrm{B}_{1}$ - With Microbial inoculants ; $\mathrm{V}_{1}: \mathrm{Mekong}_{2} \mathrm{~V}_{2}:$ California

Wonder, $\mathrm{V}_{3}$ : J K Peeyali and $\mathrm{V}_{4}$ : Asha 
Table.2 Effect of microbial inoculants and varieties on plant development and fruit attributes of bell pepper

\begin{tabular}{|c|c|c|c|c|c|c|c|c|c|c|c|c|}
\hline \multirow[t]{2}{*}{ Treatment } & \multicolumn{3}{|c|}{ Days to $50 \%$ flowering } & \multicolumn{3}{|c|}{ Days to fruit maturity } & \multicolumn{3}{|c|}{ Number of fruits/plant } & \multicolumn{3}{|c|}{ Fruit weight (g) } \\
\hline & $\mathbf{Y}_{1}$ & $\mathbf{Y}_{2}$ & Pooled & $\mathbf{Y}_{1}$ & $\mathbf{Y}_{2}$ & Pooled & $\mathbf{Y}_{1}$ & $\mathbf{Y}_{2}$ & Pooled & $Y_{1}$ & $\mathbf{Y}_{2}$ & Pooled \\
\hline \multicolumn{13}{|c|}{ Microbial inoculants } \\
\hline $\mathrm{B}_{0}$ & 98.53 & 101.19 & 99.86 & 124.14 & 127.07 & 125.61 & 7.91 & 8.13 & 8.02 & 62.29 & 64.53 & 63.41 \\
\hline $\mathrm{B}_{1}$ & 94.34 & 97.54 & 95.94 & 119.31 & 122.1 & 120.71 & 8.64 & 8.89 & 8.77 & 67.30 & 71.12 & 69.21 \\
\hline SEm \pm & 1.18 & 1.23 & 0.97 & 1.20 & 1.24 & 1.04 & 0.21 & 0.26 & 0.17 & 0.81 & 0.84 & 0.68 \\
\hline $\mathrm{CD}(\mathrm{P}=0.05)$ & 3.41 & 3.58 & 2.73 & 3.49 & 3.61 & 2.92 & 0.56 & 0.63 & 0.48 & 2.36 & 2.42 & 1.91 \\
\hline $\mathrm{V}_{1}$ & 103.31 & 105.12 & 104.22 & 131.45 & 134.37 & 132.91 & 9.13 & 9.79 & 9.46 & 66.52 & 69.59 & 68.06 \\
\hline $\mathrm{V}_{2}$ & 104.24 & 107.59 & 105.92 & 134.31 & 137.18 & 135.75 & 6.87 & 6.98 & 6.93 & 42.34 & 45.12 & 43.73 \\
\hline $\mathrm{V}_{3}$ & 92.73 & 96.18 & 94.46 & 109.18 & 111.22 & 108.70 & 7.69 & 7.83 & 7.76 & 57.21 & 60.13 & 58.67 \\
\hline $\mathrm{V}_{4}$ & 86.4 & 89.53 & 87.97 & 105.32 & 106.28 & 106.29 & 8.73 & 8.91 & 8.82 & 83.24 & 86.4 & 84.82 \\
\hline SEm \pm & 1.10 & 1.14 & 0.89 & 1.18 & 1.22 & 0.99 & 0.29 & 0.32 & 0.24 & 0.85 & 0.89 & 0.73 \\
\hline \multicolumn{13}{|l|}{ Interaction } \\
\hline $\mathrm{B}_{0} \mathrm{~V}_{3}$ & 93.34 & 97.03 & 95.19 & 108.51 & 112.32 & 110.42 & 7.81 & 7.93 & 7.87 & 59.19 & 61.42 & 60.30 \\
\hline $\mathrm{B}_{0} \mathrm{~V}_{4}$ & 85.39 & 87.30 & 86.35 & 105.11 & 108.20 & 106.66 & 8.83 & 8.96 & 8.90 & 85.52 & 88.16 & 86.84 \\
\hline $\mathrm{B}_{1} \mathrm{~V}_{1}$ & 98.36 & 97.24 & 97.80 & 127.51 & 131.14 & 129.33 & 9.83 & 10.21 & 10.02 & 73.39 & 76.41 & 74.90 \\
\hline $\mathrm{B}_{1} \mathrm{~V}_{2}$ & 101.22 & 98.39 & 99.81 & 128.27 & 132.08 & 130.18 & 7.26 & 7.68 & 7.47 & 50.11 & 53.39 & 51.75 \\
\hline $\mathrm{B}_{1} \mathrm{~V}_{3}$ & 89.48 & 94.12 & 91.80 & 103.34 & 107.89 & 105.62 & 8.27 & 8.89 & 8.58 & 63.37 & 67.24 & 65.31 \\
\hline $\mathrm{B}_{1} \mathrm{~V}_{4}$ & 83.24 & 84.17 & 83.71 & 100.24 & 102.14 & 101.19 & 9.29 & 9.58 & 9.435 & 90.24 & 94.07 & 92.16 \\
\hline SEm \pm & 1.20 & 1.27 & 0.99 & 1.29 & 1.33 & 1.06 & 0.29 & 0.35 & 0.26 & 0.91 & 0.94 & 0.81 \\
\hline $\mathrm{CD}(\mathrm{P}=0.05)$ & 3.51 & 3.78 & 2.84 & 3.78 & 3.87 & 3.04 & 0.78 & 0.96 & 0.75 & 2.56 & 2.67 & 2.32 \\
\hline
\end{tabular}

$\mathrm{Y}_{1}: 2011-12 ; \mathrm{Y}_{2}: 2012-13$; Treatments: $\mathrm{B}_{0}:$ No Microbial inoculants, $\mathrm{B}_{1}$ - With Microbial inoculants ; $\mathrm{V}_{1}: \mathrm{Mekong}_{2} \mathrm{~V}_{2}:$ California

Wonder, $\mathrm{V}_{3}$ : J K Peeyali and $\mathrm{V}_{4}$ : Asha 
Table.3 Effect of microbial inoculants and varieties on yield and quality attributes of bell pepper

\begin{tabular}{|c|c|c|c|c|c|c|c|c|c|c|c|c|}
\hline \multirow[t]{2}{*}{ Treatment } & \multicolumn{3}{|c|}{ Fruit yield/plant(g) } & \multicolumn{3}{|c|}{ Fruit yield /ha(ton) } & \multicolumn{3}{|c|}{ Beta Carotene $(\mu \mathrm{g} / 100 \mathrm{~g})$} & \multicolumn{3}{|c|}{ Vitamin C (mg/100 g) } \\
\hline & $\mathbf{Y}_{1}$ & $\mathbf{Y}_{2}$ & Pooled & $\mathbf{Y}_{1}$ & $\mathbf{Y}_{2}$ & Pooled & $Y_{1}$ & $\mathbf{Y}_{2}$ & Pooled & $\mathbf{Y}_{1}$ & $\mathbf{Y}_{2}$ & Pooled \\
\hline \multicolumn{13}{|c|}{ Microbial inoculants } \\
\hline $\mathrm{B}_{0}$ & 563.12 & 569.20 & 566.16 & 13.21 & 13.60 & 13.41 & 0.64 & 0.67 & 0.66 & 123.54 & 126.87 & 125.21 \\
\hline $\mathrm{B}_{1}$ & 576.31 & 581.13 & 578.72 & 14.43 & 14.81 & 14.62 & 0.71 & 0.74 & 0.73 & 134.27 & 139.19 & 136.73 \\
\hline SEm \pm & 7.51 & 8.40 & 7.22 & 0.31 & 0.36 & 0.28 & 0.008 & 0.009 & 0.006 & 1.17 & 1.23 & 0.97 \\
\hline $\mathrm{CD}(\mathrm{P}=0.05)$ & 20.86 & 23.34 & 20.29 & 0.85 & 0.98 & 0.79 & 0.022 & 0.025 & 0.017 & 3.40 & 3.61 & 2.73 \\
\hline \multicolumn{13}{|l|}{ Variety } \\
\hline $\mathrm{V}_{1}$ & 674.41 & 686.35 & 680.38 & 16.14 & 17.23 & 16.69 & 0.71 & 0.73 & 0.72 & 146.08 & 148.84 & 147.46 \\
\hline $\mathrm{V}_{2}$ & 271.23 & 284.14 & 277.69 & 7.43 & 7.62 & 7.53 & 0.73 & 0.76 & 0.75 & 149.24 & 152.36 & 150.80 \\
\hline $\mathrm{V}_{3}$ & 456.12 & 463.29 & 459.71 & 12.81 & 13.06 & 12.94 & 0.61 & 0.63 & 0.62 & 109.31 & 111.22 & 110.27 \\
\hline $\mathrm{V}_{4}$ & 608.32 & 619.35 & 613.84 & 15.79 & 15.96 & 15.88 & 0.70 & 0.72 & 0.71 & 135.27 & 137.09 & 136.18 \\
\hline SEm \pm & 9.23 & 9.61 & 8.68 & 0.41 & 0.44 & 0.30 & 0.007 & 0.008 & 0.005 & 1.29 & 1.32 & 1.03 \\
\hline $\mathrm{CD}(\mathrm{P}=0.05)$ & 26.21 & 27.59 & 23.57 & 1.12 & 1.22 & 0.81 & 0.020 & 0.022 & 0.014 & 3.78 & 3.89 & 2.80 \\
\hline \multicolumn{13}{|l|}{ Interaction } \\
\hline $\mathrm{B}_{0} \mathrm{~V}_{1}$ & 681.24 & 687.19 & 684.22 & 17.11 & 17.72 & 17.42 & 0.70 & 0.74 & 0.720 & 149.11 & 151.24 & 150.18 \\
\hline $\mathrm{B}_{0} \mathrm{~V}_{2}$ & 286.13 & 291.34 & 288.74 & 7.65 & 7.84 & 7.75 & 0.75 & 0.78 & 0.765 & 147.32 & 148.16 & 147.74 \\
\hline $\mathrm{B}_{0} \mathrm{~V}_{3}$ & 461.34 & 467.51 & 464.43 & 12.96 & 13.16 & 13.06 & 0.60 & 0.64 & 0.620 & 108.28 & 110.31 & 109.30 \\
\hline $\mathrm{B}_{0} \mathrm{~V}_{4}$ & 623.39 & 632.44 & 627.92 & 15.91 & 16.03 & 15.97 & 0.69 & 0.71 & 0.700 & 136.54 & 138.10 & 137.32 \\
\hline $\mathrm{B}_{1} \mathrm{~V}_{1}$ & 694.18 & 708.14 & 701.16 & 17.84 & 18.11 & 17.98 & 0.73 & 0.76 & 0.745 & 151.29 & 152.24 & 151.77 \\
\hline $\mathrm{B}_{1} \mathrm{~V}_{2}$ & 298.31 & 312.27 & 305.29 & 7.79 & 8.09 & 7.94 & 0.78 & 0.80 & 0.790 & 151.83 & 155.01 & 153.42 \\
\hline $\mathrm{B}_{1} \mathrm{~V}_{3}$ & 473.04 & 486.39 & 479.72 & 13.58 & 13.87 & 13.73 & 0.64 & 0.67 & 0.655 & 110.68 & 112.38 & 111.53 \\
\hline $\mathrm{B}_{1} \mathrm{~V}_{4}$ & 644.38 & 661.14 & 652.76 & 16.31 & 16.79 & 16.55 & 0.72 & 0.74 & 0.730 & 137.18 & 139.78 & 138.48 \\
\hline SEm \pm & 9.81 & 9.96 & 8.98 & 0.49 & 0.54 & 0.38 & 0.008 & 0.009 & 0.007 & 1.46 & 1.54 & 1.21 \\
\hline $\mathrm{CD}(\mathrm{P}=0.05)$ & 28.31 & 29.42 & 25.77 & 1.34 & 1.51 & 1.09 & 0.023 & 0.026 & 0.020 & 4.29 & 4.53 & 3.47 \\
\hline
\end{tabular}

$\mathrm{Y}_{1}$ :2011-12; $\mathrm{Y}_{2}$ :2012-13; Treatments: $\mathrm{B}_{0}$ : No Microbial inoculants, $\mathrm{B}_{1}$ - With Microbial inoculants ; $\mathrm{V}_{1}$ : Mekong, $\mathrm{V}_{2}$ :

California Wonder, $\mathrm{V}_{3}$ : J K Peeyali and $\mathrm{V}_{4}$ : Asha 
The variety Mekong proved superior due to difference in mineralization, availability and utilization of nutrients by the plants. Among quality attributes, beta carotene content and vitamin $\mathrm{C}$ content were found highest in California Wonder.

\section{Interaction effect between microbial inoculants and varieties}

The interaction effect showed that growth and yield attributes of bell pepper were significantly influenced by combination of microbial inoculants and varieties. The result showed that all the varieties showed superior performance when seedlings were treated with microbial inoculants. The highest plant height $(45.93 \mathrm{~cm})$, leaf area $\left(6.65 \mathrm{~cm}^{2}\right)$ and Leaf chlorophyll content (64.47 SPAD value) were produced by the variety Asha when seedlings were dipped with microbial inoculants. The same variety recorded minimum days for $50 \%$ flowering (83.71 days), fruit maturity (101.19 days) as well as maximum fruit weight $(92.16 \mathrm{~g})$ when treated with microbial inoculants. The maximum number of fruits (10.02/plant) along with highest fruit yield (701.16 g/plant and $17.98 \mathrm{t} / \mathrm{ha}$ ) were recorded by the variety Mekong treated with microbial inoculants. The results on quality attributes indicated that both beta carotene and ascorbic acid content of fruit were found maximum for California Wonder in presence of microbial inoculants. Earliness in flower formation and fruit maturity in presence of microbial inoculants could be attributed to enhanced vegetative growth coupled with adequate reserved food material which facilitated early differentiation of vegetative buds and results in advance flower formation and subsequently early maturity of the fruit. Microbial inoculants enhances phytohormone production, nitrogen fixation, phosphate solubilization and specific activities of enzymes involved in the metabolic pathway might be the reason behind growth and yield improvement of the plant (Bashyal, 2011). Enhancement of bell pepper yield in presence of microbial bioinoculants has been reported by Dhruba et al., (2011) and TayebRezvani et al., (2013).

The experimental findings showed that seedling root dipping with Azotobacter and Phosphate Solubilizing Bacteria containing microbial inoculants offer great potential for bell pepper cultivation and the performance of the varieties enhanced greatly in presence of microbial inoculants. The positive effect of microbial inoculants was expressed in enhancing the growth and yield attributes. The practice will help to achieve desired yield, augment nutrient efficiency and will be beneficial for sustainability of the bell pepper cultivation.

\section{References}

Abd El-Fattah, D.A., Ewedab, W.E., Zayed, M.S. and Hassaneina, M.K. 2013. Effect of carrier materials, sterilization method and storage temperature on survival and biological activities of Azotobacter chroococcum inoculants. Ann. Agric. Sci., 58: 111-118.

Bashyal, L.N. 2011. Response of cauliflower to nitrogen fixing biofertilizer and graded levels of nitrogen. J. Agri. Env., 12 : 41-50.

Dhruba, R., Bhattarai, Poudyal, K.P. and Pokhrel, S. 2011. Effect of Azotobacter and nitrogen levels on fruit yield and quality of bell pepper, Nepal J. Sci.Tech., 12: 29-34.

Hazra, P., Chattopadhyay, A., Karmakar, K. and Dutta, A. 2011. Modern technology in vegetable production. New India Publishing Agency, New Delhi, India.

Kaushal, M., Kaushal, R., Thakur, B.S. and 
Spehia, R.S. 2011. Effect of plant growth-promoting rhizobacteria at varyinglevels of $\mathrm{N}$ and $\mathrm{P}$ fertilizers on growth and yield of cauliflower in mid hills of Himachal Pradesh. J. Farm Sci., 1(1) : 19-26.

Kumar, V. and Ahlawat, I.P.S. 2006. Effect of bio-fertilizers and nitrogen on wheat (Triticum aestivum) and their after effects on succeeding maize in wheat-maize cropping system. Indian J. Agril. Sci., 76 : 465-68.

Kute, S., Patel, B., Maheshwari, R. and Chaturvedi, P. 1997. Bio-fertilizers, The GSFC approach. Bio-energy for rural energisation, pp 175-195.

Mohammadi, K., Yousef Sohrabi, Y. 2012. Bacterial Biofertilizers for sustainable crop production: A review. J. Agric. Biol. Sci., 7: 307-316.

Ranganna, S. 2001. Analysis and quality control for fruits and vegetable products, Tata Mc Grawhill Publication. $2^{\text {nd }}$ Edition, New Delhi, pp. 110-12.

Sahoo, R.K., Ansari, M.W., Dangar, T.K.,
Mohanty Sand Tuteja, N. 2013. Phenotypic and molecular characterization of efficient nitrogen fixing Azotobacter strains of the rice fields. Protoplasm, 13: 547-552.

Sindhu, S.S., Suneja, S. and Dadarwall, K.R. 1997. Plant growth promoting rhizobacteria and their role in crop productivity, In: Biotechnological approaches in soil microorganism for sustainable crop production, edited by Dadarwall K R (Scientific publisher, Jodhpur). 149-170 pp.

Singh, J.S., Pandey, V.C. and Singh, D.P. 2011. Efficient soil microorganisms: a new dimension for sustainable agriculture and environmental development. Agric. Ecosyst. Environ., 140: 339-353.

TayebRezvani, H.P., Moradi and Soltani, F. 2013. The effect of nitrogen fixation and phosphorus solvent bacteria on growth physiology and vitamin $\mathrm{C}$ content of Capsicum annum L. Iranian J. Plant Physiol., 3(2): 673-682.

\section{How to cite this article:}

Ranjit Chatterjee, Sagar Koner and Suchand Datta. 2016. Impact of Microbial Inoculants on the Performance of Bell Pepper (Capsicum annuum L.) Varieties under Foot Hills of Eastern Himalayan Region. Int.J.Curr.Microbiol.App.Sci. 5(9): 131-138. doi: http://dx.doi.org/10.20546/ijcmas.2016.509.015 